\title{
KECEMASAN DAN KUALITAS HIDUP PADA PENDERITA KANKER OVARIUM
}

\author{
Anxiety and Quality of Life in Patient with Ovarian Cancer \\ Made Ririn Sri Wulandari \\ Departemen Keperawatan Maternitas STIKES Bina Usada Bali \\ Korespondensi : mdririns@gmail.com
}

\begin{abstract}
ABSTRAK
Kualitas hidup pasien kanker sangat penting untuk diketahui, terutama pada aspek kecemasan. Kecemasan sering menjadi komponen yang tidak penting untuk penelitian, namun ternyata penting untuk diketahui pada wanita penderita ovarian cancer. Tujuan Penelitian untuk mengidentifikasi kualitas hidup dan kecemasan pada wanita penderita kanker ovarium. Penelitian ini merupakan penelitian kuantitatif dengan metode survey menggunakan kuisioner, subyek penelitian adalah wanita penderita kanker ovarium sebanyak 41 responden dengan memenuhi kriteria inklusi dan eksklusi. Karakteristik responden penderita kanker servik rerata terbanyak adalah pada usia $>45$ tahun, dengan status ekonomi rendah, berpendidikan rendah, dan lama menderita kanker $>6$ bulan. Hasil survey yang didapatkan adalah pada skala gejala terdapat domain sosial yang memiliki nilai rerata tertinggi $83,29 \pm 23,87$ dan skala gejala nilai rerata tertinggi adalah kelelahan $50,44 \pm 26,93$. Skor kecemasan pada responden memiliki rerata 29,83 $\pm 24,72$ yang berarti mengalami kecemasan sedang. Pelayanan pendukung dapat lebih ditingkatkan ini sesuai dengan hasil penelitian yang didapat, bahwa perlu adanya pembinaan spiritual atau layanan khusus psikologis pada pasien yang sudah dalam tahap terminal, sehingga hal tersebut dapat membantu pasien untuk semangat hidup dalam melawan kanker maupun mencapai kematian yang damai
\end{abstract}

Kata kunci: kecemasan, kualitas hidup, kanker ovarium

\begin{abstract}
The quality of life for cancer patients is very important to know, especially in the aspect of anxiety. Anxiety is often a component that is not important for research, but it is important to know for women with ovarian cancer. To identify quality of life and anxiety in women with ovarian cancer. This is a quantitative study and survey method using questionnaires, subjects were 41 ovarian cancer women who met inclusion and exclusion criteria. The highest respondent characteristics of patients with average cervical cancer were at the age of $>45$ years, with a low economic status, low education, and long duration of cancer $>6$ months. The survey results obtained were on the symptom scale there was a social domain which had the highest average value of $83.29 \pm 23.87$ and the highest symptom scale score was fatigue 50.44 \pm 26.93 . The score of anxiety in the respondents had a mean of $29.83 \pm 24.72$ which meant experiencing moderate anxiety. This support service can be further improved according to the results of the research obtained, that there is a need for spiritual guidance or psychological special services for patients who are already in the terminal stage, so that it can help patients to live in fighting cancer and achieving peaceful death.
\end{abstract}

Keywords: anxiety, quality of life, ovarian cancer 


\section{PENDAHULUAN}

Kanker selalu dianggap sebagai penyakit yang serius dan membuat seseorang yang telah terdiagnosa menjadi putus asa. Penyakit kanker selalu mengingatkan seseorang semakin dekat dengan kematian yang menyakitkan dan menimbulkan rasa cemas (Alacacioglu, et al., 2013). Kanker ovarium sering disebut dengan "silent killer", karena pada masa awal berkembangnya cenderung tanpa gejala atau keluhan, hal ini yang menyebabkan kanker ovarium sulit untuk dideteksi sejak dini. Penderita kanker ovarium terdeteksi dan terdiagnosa tegak sudah dalam stadium lanjut lebih dari $70 \%$. Keluhan yang sering dirasakan pada penderita kanker ovarium adalah merasakan sakit dibagian abdominal (perut bawah) dengan disertai rasa kembung, sulit untuk buang air besar, sering buang air kecil, sakit kepala (Busmar, 2006). Wanita yang mengalami kanker ovarium stadium lanjut, maka gejala yang dirasakan akan semakin bertambah parah atau membuat semakin tidak nyaman seperti adanya rasa tidak nyaman dibagian perut bawah selama menstruasi, rasa kejang diperut, pendarahan vagina yang tidak normal serta nyeri diseputar kaki (Rahayu, 2010).

Pengobatan kanker yang didapat seperti pembedahan, kemoterapi, dan radioterapi dapat menimbulkan suatu efek baik secara fisik, kehilangan nyawa, dihadapkan pada status sosial yang baru, merasa kehilangan kehidupan yang normal, dimana hal-hal tersebut menimbulkan efek pada psikologis, terutama kecemasan. Penelitian yang dilakukan oleh Farooqi dan Chaudhry (2012), menunjukkan bahwa pasien dengan kanker ginekologi lebih tinggi tingkat kecemasannya dibandingkan dengan kanker payudara, hal ini kemungkinan dapat mengancam kemampuan wanita dalam bereproduksi yang pada hakekatnya wanita harus menjadi seorang istri dan seorang ibu. Penyebab dari kecemasan pada kanker itu sendiri, disebabkan oleh kombinasi dari faktor biologis, faktor sosial, dan faktor psikologis. Pada faktor biologis, kecemasan timbul karena otak menstimulasi HPA-axis di korteks cerebri yang mempengaruhi hipotalamus, dimana hipotalamus itu akan memicu hipofisis anterior memproduksi
ACTH (adenocorticotrophic hormone), kemudian ACTH merangsang korteks adrenal melepas hormon stres (kortisol) yang akan menimbulkan respon cemas (Gask \& Graham, 2014).

Beberapa gejala fisik yang timbul akibat dari kanker ovarium ini juga dapat mempengaruhi respon kecemasan pasien. Ketika seseorang terdiagnosa kanker ovarium gejala yang timbul seperti terjadinya perdarahan ketika bersenggama atau diluar dari masa haid menimbulkan rasa cemas karena seorang wanita merasa tidak normal akibat dampak dari disfungsi seksual terhadap pasangannya. Selain itu, beberapa wanita yang telah mengetahui dirinya terdiagnosa kanker ovarium memiliki pemikiran bahwa kanker ovarium akan mengakibatkan kemandulan (infertilitas) karena efek dari pengobatan yang akan dilakukan seperti operasi dan kemoterapi, dan hal tersebut dapat mencetuskan rasa cemas pada seorang wanita (Chan, J., et al, 2015; Berek, 2012). Reis, Beji, dan Coskun (2010) menyatakan bahwa prosedur dari perawatan kanker merupakan masalah yang penting dan juga memiliki efek negatif pada fisik, psikologis, sosial dan juga aspek spiritual yang merupakan bagian dari kualitas hidup. Hasil dari penelitian tersebut menjelaskan bahwa kualitas hidup memiliki hubungan kuat dengan jenis pengobatan seperti (perawatan lanjutan, kemoterapi, radioterapi, dan kombinasi beberapa perawatan lainnya). Penjelasan terkait kualitas hidup menunjukkan bahwa kualitas hidup dipengaruhi oleh beberapa faktor termasuk karakteristik pasien. Oleh karena itu, mempertahankan kualitas hidup pasien penderita kanker sangat penting dengan memperhatikan faktor lain yang mempengaruhi, sehingga dapat meminimalkan dampak yang akan memperburuk keadaan pasien selama kelangsungan hidupnya.

\section{TUJUAN PENELITIAN}

Tujuan dilakukannya penelitian adalah untuk mengidentifikasi kecemasan dan kualitas hidup wanita penderita kanker ovarium. 


\section{METODELOGI PENELITIAN}

Desain

Penelitian ini merupakan penelitian kuantitatif dengan desain penelitian deskriptif pendekatan cross-sectional.

\section{Populasi dan Sampel}

Populasi dalam penelitian ini adalah seluruh pasien kanker ovarium di RSUP Dr. Sardjito Yogyakarta. Subyek penelitian yang diambil dalam penelitian ini adalah sebanyak 41 responden penderita kanker ovarium stadium lanjut, dengan kriteria inklusi bersedia menjadi responden, wanita dengan kanker ovarium stadium lanjut, yaitu stadium IIB-IV, pasien rawat inap dan rawat jalan yang terdiagnosa utama kanker ovarium yang telah mendapatkan kemoterapi dirawat di ruang Bugenvil I, dan di Poli Obstetri Ginekologi, dapat berkomunikasi dengan baik secara lisan dan tulisan, sedangkan kriteria eksklusi pasien yang dalam keadaan tidak sadar atau sedang dalam kondisi kesehatan yang lemah. Metode pengambilan sampel menggunakan metode non-probability sampling jenis purposive sampling.

\section{Tempat dan Waktu Penelitian}

Penelitian ini dilaksanakan di RSUP

Dr. Sardjito Yogyakarta selama 16 minggu.
Instrumen dan Prosedur Pengukuran

Pengambilan data penelitian menggunakan kuisioner EORTC QOL C30 untuk mengukur kualitas hidup dan VAS-A untuk mengukur kecemasan pasien penderita kanker ovarium. Kualitas hidup akan diukur pada pasien yang telah mendapatkan kemoterapi semua siklus, dan menjawab pertanyaan 3 domain dalam kuisioner. Setelah mengisi kuisioner kualitas hidup, dilanjutkan dengan mengukur skala kecemasan. Pasien akan memberi tanda garis vertical antara garis 0-100 sebagai bentuk intrepretasi kecemasan yang dirasakan oleh pasien.

\section{Analisa Data}

Analisa pada data adalah analisa univariate pada karakteristik responden, kualitas hidup dan kecemasan.

\section{HASIL PENELITIAN}

Karakteristik responden pada penelitian ini yaitu usia, lama rawat, lama sakit, tingkat pendidikan, pekerjaan, penghasilan keluarga yang berhubungan dengan status ekonomi, siklus kemoterapi yang didapatkan pasien, dan tingkat stadium lanjut. Berikut hasil survey yang dapat dilihat pada tabel 1.

\begin{tabular}{|c|c|c|}
\hline $\begin{array}{l}\text { Karakteristik } \\
\text { Responden }\end{array}$ & $\mathrm{n}(\%)$ & $\begin{array}{l}\text { Mean } \pm \mathrm{SD} \\
\text { (min-max) }\end{array}$ \\
\hline \multicolumn{3}{|l|}{ 1. Usia } \\
\hline$\leq 25$ th & $1(2,4)$ & $50,27 \pm 9,85$ \\
\hline $36-45$ th & $9(22,0)$ & $(23-66)$ \\
\hline$>45$ th & $31(75,6)$ & \\
\hline \multicolumn{3}{|l|}{ 2. Lama dirawat } \\
\hline$\leq 2$ hari & $25(46,3)$ & $2,02 \pm 0,93$ \\
\hline$>2$ hari & $16(76,2)$ & $(1-6)$ \\
\hline \multicolumn{3}{|l|}{ 3. Lama sakit } \\
\hline$\leq 6$ bulan & $13(56,5)$ & $11,09 \pm 6,67$ \\
\hline$>6$ bulan & $28(53,8)$ & $(4-36)$ \\
\hline \multicolumn{3}{|l|}{ 4. Pendidikan } \\
\hline Tinggi & $5(71,4)$ & \\
\hline Sedang & $12(54,5)$ & \\
\hline Rendah & $24(52,2)$ & \\
\hline \multicolumn{3}{|l|}{ 5. Pekerjaan } \\
\hline Bekerja & $18(54,5)$ & \\
\hline Tidak Bekerja & $23(54,8)$ & \\
\hline $\begin{array}{l}\text { 6. Penghasilan } \\
\leq 1.500 .000\end{array}$ & $25(53,2)$ & \\
\hline
\end{tabular}




\begin{tabular}{lc}
\hline$>1.500 .000$ & $16(57,1)$ \\
\hline 7. Siklus Kemoterapi & \\
Siklus 2-3 & $17(50)$ \\
Siklus 4-6 & $24(58,5)$ \\
\hline 8. Stadium & \\
Stadium IIB & $4(22,2)$ \\
Stadium III & $32(68,1)$ \\
Stadium IV & $5(50)$ \\
\hline Ket:Data primer. SD = Standar deviasi, Mean = Rerata
\end{tabular}

Pada tabel 2 menjabarkan terkait hasil survey kualitas hidup dan tingkat kecemasan yang dialami oleh wanita penderita kanker ovarium. Nilai rerata skala fungsional dan skala kesehatan umum yang tinggi menunjukkan status fungsi dan kesehatan umum pasien kanker ovarium semakin baik. Nilai rerata skala gejala yang tinggi menunjukkan status gejala yang dirasakan pasien ovarium semakin memburuk. Pada skala fungsional nilai rerata tertinggi adalah fungsi sosial dan yang terendah adalah fungsi fisik, yang menandakan bahwa pada pasien kanker ovarium fungsi fisik semakin buruk. Pada skala gejala nilai rerata tertinggi adalah kelelahan dan kesulitan tidur, yang menandakan pasien kanker ovarium stadium lanjut merasakan gejala yang paling berat adalah kesulitan tidur dan kelelahan.

Tabel 2. Kualitas Hidup dan Kecemasan Pasien Kanker Ovarium (n=41)

\begin{tabular}{|c|c|c|}
\hline \multirow[t]{2}{*}{ Variabel } & \multicolumn{2}{|c|}{$\begin{array}{l}\text { Kanker ovarium } \\
n=41\end{array}$} \\
\hline & $($ Mean $\pm \mathrm{SD})$ & $\begin{array}{l}\text { Median } \\
\text { (Range) }\end{array}$ \\
\hline $\begin{array}{l}\text { Kualitas Hidup (EORTC } \\
\text { C30) }\end{array}$ & & \\
\hline $\begin{array}{l}\text { 1. Skala fungsional } \\
\text { Fungsi fisik } \\
\text { Fungsi peran } \\
\text { Fungsi emosional } \\
\text { Fungsi kognitif } \\
\text { Fungsi sosial }\end{array}$ & $\begin{array}{l}64,88 \pm 27,37 \\
69,54 \pm 38,34 \\
83,19 \pm 20,47 \\
80,80 \pm 24,33 \\
83,29 \pm 23,87\end{array}$ & $\begin{array}{c}80(7-93) \\
83(0-100) \\
92(25-100) \\
83(17-100) \\
100(17-100)\end{array}$ \\
\hline 2. Skala gejala & & \\
\hline Kelelahan & $50,44 \pm 26,93$ & $56(0-100)$ \\
\hline Mual dan muntah & $18,65 \pm 30,74$ & $0(0-100)$ \\
\hline Nyeri & $40,68 \pm 33,94$ & $50(0-100)$ \\
\hline Kesulitan bernapas & $11,39 \pm 23,17$ & $0(0-67)$ \\
\hline Kesulitan tidur & $44,68 \pm 37,79$ & $33(0-100)$ \\
\hline Kehilangan nafsu makan & $23,58 \pm 30,12$ & $0(0-100)$ \\
\hline Konstipasi & $13,80 \pm 27,88$ & $0(0-100)$ \\
\hline Diare & $8,12 \pm 22,10$ & $0(0-100)$ \\
\hline Kesulitan keuangan & $40,68 \pm 41,23$ & $33(0-100)$ \\
\hline 3. Skala kesehatan umum & $68,56 \pm 19,12$ & $67(25-100)$ \\
\hline Kecemasan (VAS-A) & $29,83 \pm 24,72$ & $24(1-90)$ \\
\hline
\end{tabular}

\section{PEMBAHASAN}

Berdasarkan hasil survey karakteristik responden wanita penderita kanker ovarium terbanyak pada umur diatas $>45$ tahun dan lama mereka telah menderita kanker ini rata-rata lebih dari 6 bulan. Pendidikan pasien sebagian besar rendah dan berpenghasilan dibawah $\mathrm{Rp} 1.500 .000$, yang berarti rata-rata penderita memiliki status sosial ekonomi yang rendah. Pada 
pasien kanker ovarium, gejala yang paling tinggi dikeluhkan berdasarkan hasil survey adalah gejala kelelahan, kesulitan tidur, nyeri, dan kesulitan akan keuangan dalam keluarga. Hal ini sejalan dengan hasil penelitian yang dilakukan oleh Zamurovic \& Perisic (2009) bahwa nilai tertinggi pada domain kualitas hidup pasien kanker ovarium adalah gejala kelelahan yang berhubungan dengan terapi pengobatan yang didapatkan oleh pasien tersebut. Kelelahan yang terjadi pada berhubungan erat dengan kejadian anemia pada pasien kanker stadium lanjut, selain itu kesulitan tidur, kehilangan nafsu makan juga merupakan penyebab dari terjadinya kelelahan dan hal ini merupakan salah satu alasan dalam penurunan kualitas hidup pasien (Latvala, et al, 2009). Temuan pada penelitian lainnya oleh Deshields, T.L (2011) juga menjelaskan bahwa pasien kanker yang mengalami kesejahteraan fisik yang rendah sering mengalami kelelahan dan kesulitan tidur, sedangkan nyeri merupakan keluhan yang paling umum pada penderita kanker.

Salah satu domain yang memiliki nilai rerata tertinggi adalah skala fungsi sosial. Secara riil didapatkan fungsi sosial bersumber dari dua pertanyaan didalam kuesioner yang mencakup kondisi kehidupan keluarga terkait kondisi fisik pasien saat ini dan aktivitas sosial pasien. Fungsi sosial dalam domain kualitas hidup mencakup aktivitas di lingkungan, kebebasan berinteraksi, mengelola hubungan interpersonal, dan juga dukungan sosial (WHO, 1997, cit Nursalam, 2013). Hasil penelitian diperkuat dengan penelitian yang dilakukan oleh Effendy, et al (2014) tentang keterlibatan keluarga dalam merawat pasien dengan kanker dan kualitas hidupnya. Penelitian ini menjelaskan bahwa Indonesia merupakan budaya yang memiliki ikatan keluarga yang kuat, yaitu jika terdapat anggota keluarga yang sakit maka keluarga merupakan kunci dalam menentukan keputusan pengobatan dan juga perawatan, sehingga hal tersebut dapat menimbulkan masalah psikososial bagi pasien.

Berhubungan dengan adanya ikatan yang kuat dalam keluarga, hal ini juga mempengaruhi psikologis pasien. Sebagian besar keluarga pasien menemani mereka di rumah sakit selama 24 jam secara bergantian antar anggota keluarga atau tetangga, sehingga timbul pemikiran pasien yang merasa menjadi beban keluarga atau beban orang lain selama sakit. Hal ini secara tidak langsung akan mengakibatkan anggota keluarga maupun pasien yang bekerja akan kehilangan waktu produktif untuk menghasilkan uang. Beberapa responden dalam penelitian ini juga merupakan ibu yang bekerja. Berdasarkan pengalaman pasien yang masih bekerja, mereka sebagian besar harus berhenti bekerja karena harus melakukan pengobatan dan juga karena keparahan dari penyakit yang membuat pasien terbatas dalam melakukan aktivitas sehari-hari.

Selain gejala kelelahan, adapun gejala lain yang memiliki nilai rerata tertinggi yaitu gejala nyeri dan kesulitan tidur. Nyeri merupakan salah satu komponen yang mempengaruhi kualitas hidup, yang sangat berhubungan dengan kemampuan seorang pasien dalam menjalani proses pengobatan serta bertahan hidup melawan kanker, dan akan semakin bertambah yang dirasakan apabila sudah berada pada stadium lanjut (Paice \& Ferrel, 2011). Dalam literatur sistematik review, didapatkan bahwa nyeri berhubungan dengan tingkat kecemasan yang dirasakan pasien. Persepsi nyeri yang dirasakan oleh penderita kanker dapat berbeda tergantung dari interaksi kompleks pada saraf. Tekanan psikologis yang dirasakan oleh pasien kanker akan memberikan efek rangsangan pada fisiologis pasien, sehingga rasa nyeri distimulus oleh sistem saraf simpatik ( Zara \& Baire, 2002). Responden pada penelitian ini berada pada stadium lanjut, yang berarti perkembangan penyakit menjadi lebih progresif, sehingga gejala nyeri yang dirasakan dapat bertambah dan membuat suatu keputusasaan, rasa takut, dan kecemasan yang berlebih pada pasien.

Kecemasan yang dirasakan pada responden penelitian ini rata-rata mengalami kecemasan sedang. Dilihat dari karakteristik responden penelitian ini yang rerata terbanyak adalah berpendidikan rendah dan status sosial ekonomi yang rendah. Hal ini 
didukung oleh penelitian Yolanda \& Karwur (2013), tentang tingkat kecemasan pasien kanker terhadap kemoterapi, yang menjelaskan bahwa pasien dengan minim pengetahuan dan penghasilan dibawah ratarata kesulitan untuk memenuhi kebutuhan hidup sehari-hari dan juga untuk berobat. Meskipun banyak pasien menggunakan asuransi dari pemerintah yang membantu dalam meringankan beban pengobatan namun, beberapa pasien mengeluhkan biaya hidup selama antri kamar di rumah sakit, perjalanan ke rumah sakit, uang transportasi, dan biaya hidup selama menjalani kemoterapi diluar dari biaya pemerintah. Berdasarkan hasil penelitian ini, maka peneliti berasumsi bahwa skor kecemasan pasien juga dapat disebabkan oleh status ekonomi pasien selama menjalani kemoterapi dan juga status penyakit pasien yang harus membutuhkan pengobatan lebih lanjut.

\section{KESIMPULAN \\ Implikasi}

Hasil penelitian ini menunjukkan bahwa tenaga perawat tidak hanya melihat pasien dari segi fisik, namun wajib untuk melihat dari segi psikologis pasien. Pelayanan pendukung dalam rumah sakit daerah atau rumah sakit rujukan kasus kanker sebaiknya dapat lebih ditingkatkan ini sesuai dengan hasil penelitian yang didapat terkait keputusasaan pasien dan kecemasan pasien, bahwa perlu adanya pembinaan spiritual atau layanan khusus psikologis pada pasien yang sudah dalam tahap terminal, sehingga hal tersebut dapat membantu pasien untuk semangat hidup dalam melawan kanker maupun mencapai kematian yang damai.

\section{Keterbatasan}

Dalam penelitian ini kriteria responden pada pasien yang menderita kanker ovarium merupakan pasien yang berulang pengobatannya, sehingga dalam pelaksanaannya peneliti perlu membuat catatan lengkap responden. Selain itu pasien banyak berasal dari berbagai daerah dan jenjang pendidikan yang berbeda, sehingga dalam pengisian kuisioner harus didampingi oleh asisten peneliti yang fasih berbahasa jawa untuk menghindari timbulnya intrepretasi yang berbeda dalam jawaban dari kuisioner.

\section{DAFTAR PUSTAKA}

Alacacioglu, A., Tarhan, O., Alacacioglu, I., Dirican, A., Yilmaz, U., (2013). Depression and Anxiety in Cancer Patients and Their Relatives. JBUON. Vol. 18(3), pp. 767-774.

Berek, J.S., (2012). Berek's \& Nova's Gynecology, $15^{\text {th }}$ ed. Philadelphia: Lippincott William \& Wilkins

Busmar, B., (2006). Kanker Ovarium. Dalam: Aziz, F.M., Andrijono, \& Saifuddin, B.A. Onkologi Ginekologi Edisi I. Jakarta: Yayasan Bina Pustaka Sarwono Prawirohardjo

Chan, J.L., Letourneau, J., Salem, W., Cil, A.P., et al., (2015). Sexual Satisfication and Quality of Life in Survivors of Localized Cervical and Ovarian Cancer Following FertilitySparing Surgery. Gynecology Oncology. Vol.139, pp. 141-147.

Deshields, T.L, Potter, P., Olsens., et al. (2011). Documenting the Symptoms Experience of Cancer Patients. J Support Oncol. Vol.9, pp. 216-223.

Farooqi M, Hassali MA, Knight A, et al., (2013). Cross Sectional Assessment of Health Related Quality of Life (HRQoL) among patients with cancer in Malaysia. Asian Pac J Cancer Prev. Vol. 14, pp. 3017-3021

Gask, L., \& Graham, C.C., (2014). ABC of Anxiety and Depression, $1^{s t} E d$. UK: John Wileys \& Sons, Ltd.

.Latvala, A., Syrjanen, K., Salmenoja, H., Salminen, E. (2009). Anemia and Other Predictors of Fatigue Among Patients on Palliative Therapy for Advance Cancer. Anticancer Research. Vol. 29(7), pp. 2569-2575

Nursalam, (2013). Metodologi Penelitian Ilmu Keperawatan: Pendekatan Praktis, Edisi 3. Jakarta: Salemba Medika

Rahayu, W., (2010). Mengenali, Mencegah, dan Mengobati 35 Jenis Kanker. Jakarta: Victory Inti Cipta.

Reis, N., Beji, N.K, Coskun, A., (2010). Quality of Life and Sexual 
Made Ririn Sri Wulandari : Kecemasan Dan Kualitas Hidup Pada Penderita Kanker Ovarium

Functioning in Gynecological Cancer Patient: Result from Quantitative and Qualitative Data. European Journal of Oncology Nursing, vol.14, pp. 137146.

Paice, J.A., \& Ferrel B., (2011). The Management of Cancer Pain. CA: A Cancer Journal for Clinicians. Vol 61(3), pp. 157-182. Diakses dari http://onlinelibrary.wiley.com/doi/10. 3322/caac.20112/full,

Yolanda, A.E,. \& Karwur, F.F., (2013). Tingkat Kecemasan Pasien Kanker
Serviks pada Golongan Ekonomi Rendah yang mengikuti Program Kemoterapi di RSUD Dr. Moewardi. Sains Medika. Vol. 5 (2), pp.68-61

Zamurovic, M., \& Perisic, Z., Quality of IIfe The Patients With Ovarian Cancer. The Internet Journal of Oncology. Vol. 7(2). Diakses pada https://ispub.com/IJO/7/2/8337

Zara, C., \& Baine, N., (2002). Cancer Pain and Psychological Factors. Journal of Pain and Symptom Management. 